\title{
APPLYING THE LINE OF RESISTANCE IN STUDIES ON PRICES ON THE HOUSING MARKET IN SZCZECIN
}

\author{
Józef Hozer, Prof. \\ Department of Econometrics and Statistics \\ University of Szczecin \\ e-mail:hozer@wneiz.pl \\ Anna Gdakowicz, Phd \\ Department of Econometrics and Statistics \\ University of Szczecin \\ e-mail:alatko@wneiz.pl
}

\begin{abstract}
The average price of residential real estate offered on the housing market in Szczecin has been declining since 2008. Prices on both the primary and secondary markets were regularly adjusted, disregarding the fact that the cost of 1 square meter of newly built flats was rising. Therefore, the question of how low can prices fall for the market to remain profitable arises?

The situation on the residential real estate market has been analyzed in four areas: on the primary and secondary market, as well as by offer and transaction prices. The study was conducted in Szczecin on a quarterly basis in the period of 2007-2012.
\end{abstract}

Keywords: housing market, offer price, transaction price, reproduction cost, line of resistance.

JEL Classification: R3, C53.

Citation: Hozer J., Gdakowicz A., 2014, Applying The Line Of Resistance In Studies On Prices On The Housing Market In Szczecin, Real Estate Management and Valuation, vol. 22, no. 1, pp. 72-79.

DOI: 10.2478/remav-2014-0009.

\section{Introduction}

When observing the changes in prices on the residential real estate market, we can see that they have been falling since 2008. Lower prices have been asked for by both the developers and the individual owners of flats on the secondary market. This downward adjustment of prices has been evident in all Polish cities.

The reason for such a situation can be attributed to the economic slowdown which has had a negative effect on the moods of potential buyers. The proper functioning of the housing market is threatened by increasing unemployment and decreasing salaries. The deteriorating job market directly affects the creditworthiness of people who have decided to purchase a home. Banks are now very cautious about lending money to individual buyers. To make matters worse, there are no government purchase assistance programmes for home buyers on either the primary and secondary market.

The author of this article relates the recorded prices of flats to the costs of their construction. The analysis is based on the example of the housing market in Szczecin. To begin with, some statistics concerning the local housing investment market are presented. Next, a "major investor" on the local market is defined and the risk related to this kind of business activity is determined. Further parts of the study deal with primary and secondary market trends in offer and transaction prices of $1 \mathrm{~m}^{2}$ for flats in Szczecin in the period of 2007-2012. The average prices of flats are related to their reproduction 
cost and the actual cost incurred by developers, treating this cost as a "line of resistance" for market prices of these transactions.

\section{The Analysis of the Housing Investment Market in Szczecin}

In 1997-2012, the number of flats offered on the housing market in Szczecin ranged from 1,500 in 2010 to 2,000 in 2007 (the annual average was 1,800). In the period of 2007-2010, the number of newly built flats was falling (Figure 1), but this tendency changed in the last two years of the analysis and, in 2012, as many as 1,944 new flats appeared on the market.

As the buyers' expectations as well as material status and creditworthiness grew, the size of new flats introduced on the market got bigger too. In 2007-2009, the average size of a new dwelling rose from $81 \mathrm{~m}^{2}$ in 2007 to $86 \mathrm{~m}^{2}$ in 2009. So, although the number of flats built in 2009 went down, their floor area increased in size. In the subsequent years, a reverse tendency was observed - every year more and more flats were put up for sale but their average floor area got smaller - dropping to $70 \mathrm{~m}^{2}$ in 2012.

The prospective number of new flats can be calculated on the basis of issued construction permits and newly started constructions. The completion of a building project can take as long as 3 years from the date a permit is issued (due to the duration of the investment cycle), but in the case of projects in progress, the time buyers have to wait for their newly built flats is shorter.

In 2007-2009, the number of ongoing housing projects decreased - from 2,500 to 1,500, whereas in 2010 , new investments doubled (to 3,000 flats) only to fall below 1,700 flats over the next two years. If the growing tendency observed in the preceding years had held up longer, we could have expected a considerable rise in the number of newly launched housing projects in 2013.

In the years analyzed in this study, the number of construction permits for flats revealed a falling tendency. In 2007, 3,500 permits were issued, while in 2012 - no more than 1,200. Assuming that there is a regularity of trends in the number of construction permit applications, we can expect this variable to reach about 2,000 in the next two years.

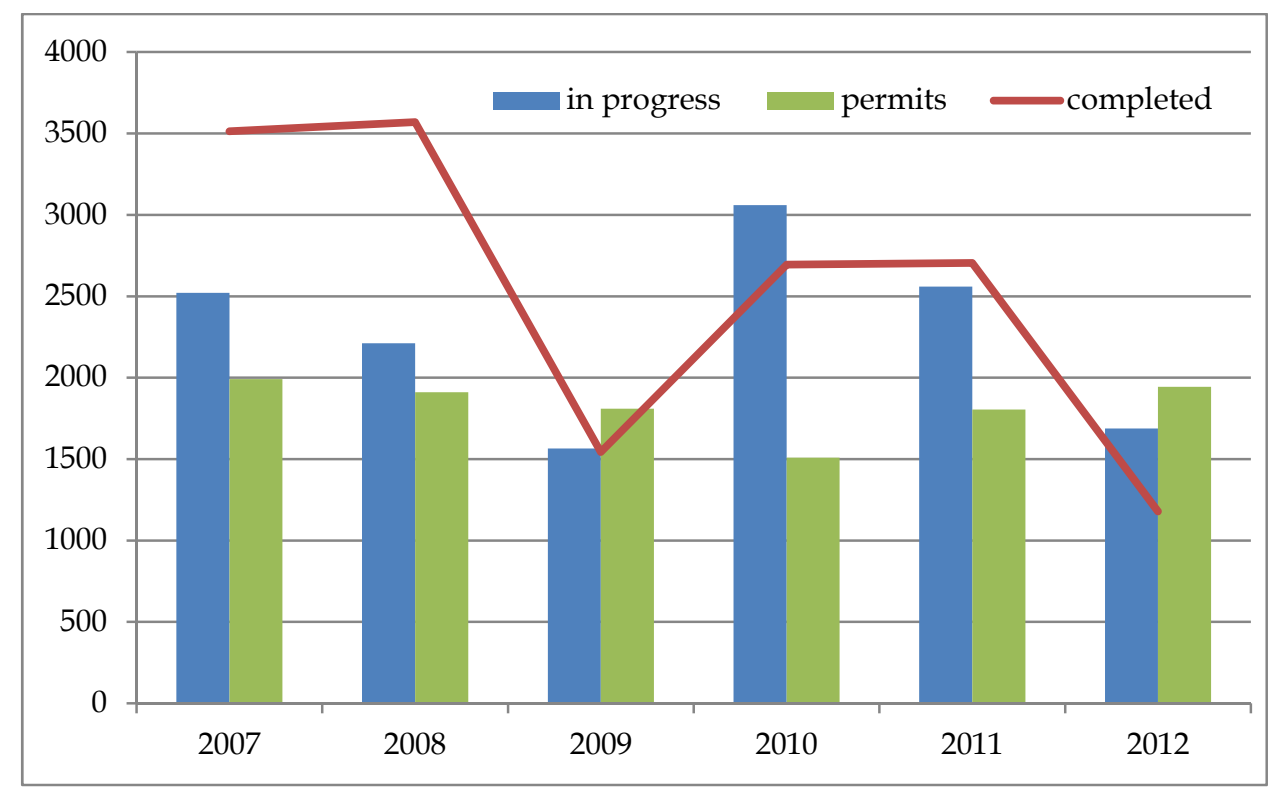

Fig. 1. The number of completed flats, newly started projects and permits issued for the construction of new flats in Szczecin in 2007-2012. Source: own study on the basis of the Local Data Bank.

In the analyzed period, changes in the structure of the group of investors investing in housing projects in Szczecin could be observed (Figure 2). In 2007, there were four types of investors, the largest being those who dealt with constructing new flats for sale or for rent (48\%). A quarter of the new flats were built for rent by social building societies (SBSs). The rest of the market was equally divided by housing cooperatives and individual investors (14\% each). In 2012, over 80\% of newly built homes were prepared for sale or for rent, while $17 \%$ were constructed by single investors, half of whom were considering resale. The share of co-ops was a mere $2 \%$, whereas social building societies 
(investing in flats for rent) did not complete a single investment in the last two years of the analyzed period.

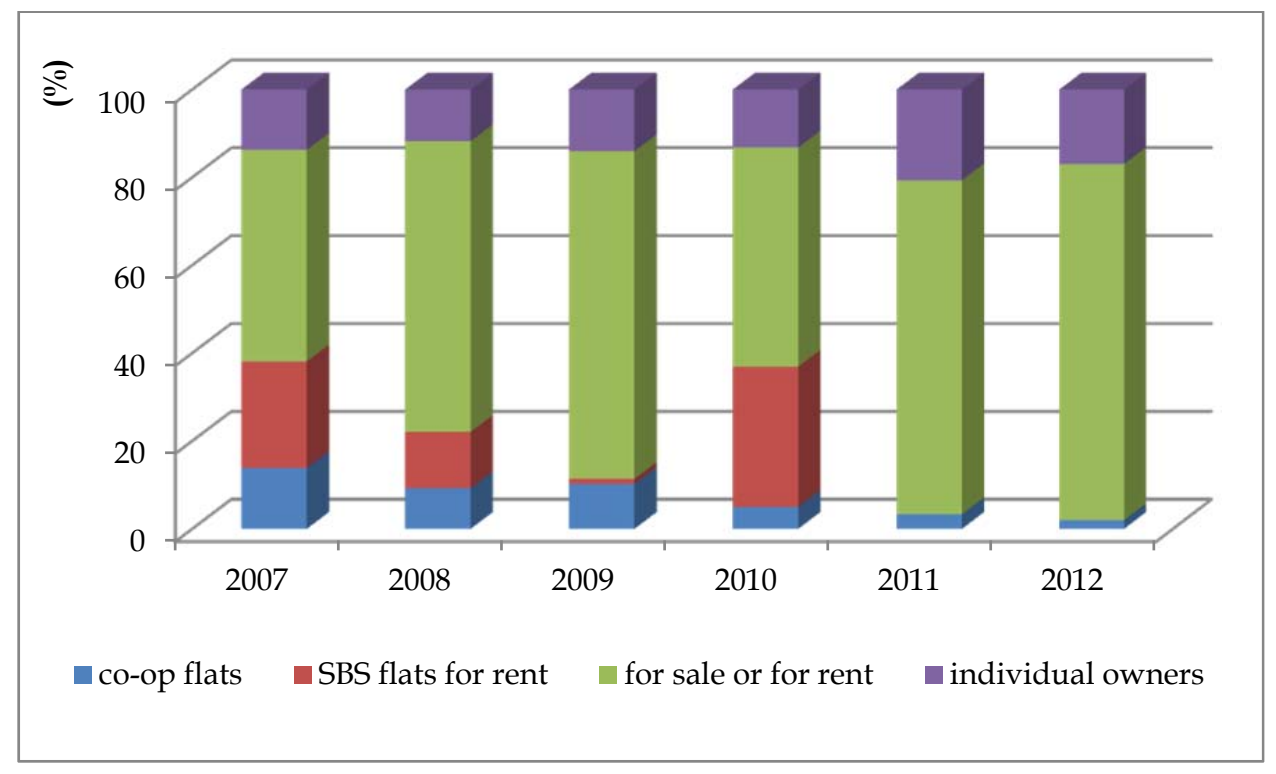

Fig. 2. Structure of newly built flats by investors - Szczecin 2007-2012. Source: own study on the basis of the Local Data Bank.

The primary housing market in Szczecin has been overtaken by developers (a similar tendency has also been observed in other Polish cities). Co-ops have systematically been backing out of the role of investors, and instead focusing on managing their property. Social building societies used to do well as investors, but after changes in legislation and a less favourable credit policy introduced by the Bank Gospodarstwa Krajowego (National Economy Bank), they have also given up new projects. Thus, the risky business of building new flats and selling them at times of economic slowdown has been taken over by real estate development companies.

\section{Risks and Costs of Residential Development Projects}

Development projects are regarded as one of the riskiest undertakings. Investments in this field require engaging substantial capital in creating a product which, by nature, is not mobile, both in time and space. Additionally, the final product (flat) enters the local market the moment the investment comes to an end, disregarding the current general economic situation.

Various types of risk referring to the development of residential projects are discussed in literature (DĄBROWSKI, KIREJCZYK 2001; GAWRON 2006):

- development risk,

- time risk,

- risk concerning construction permits,

- financing risk,

- risk concerning the construction site,

- risk of increased costs.

Development risk is associated with the pertinence of a business idea (its location and purpose), as well as with accurate prognoses and plans concerning an investment. At the initial stage of an investment, it is difficult to predict the actual conditions under which the flats will be sold after many months of construction works. Of course, the most desirable moment for such endeavours to be completed is the time of an economic boom, when the prices of $1 \mathrm{~m}^{2}$ are the highest. Time risk occurs when there is a threat that the investment project may be completed behind schedule. The delayed date of investment completion may result in flats going up for sale at a time when the situation on the real estate market is much less favourable; hence, they will be more difficult to sell.

Risk associated with obtaining construction permits relates to the fact that developers are bound by a lot of regulations. The amount of red tape involved often results in having to face unpredicted obstacles which can affect the ultimate cost and duration of the project.

Financing risk is yet another type of risk investors must account for. It results from the developer's 
dependence on external capital, with its changing interest rates and foreign exchange risk. These can fluctuate significantly, causing a potentially profitable investment to suffer a loss.

The site chosen for an investment brings about risk which is difficult to assess merely on the basis of its topographic conditions. The project can be delayed due to unexpected findings during excavation works, such as the remains of some historic buildings, unexploded WWII bombs, nontypical hydrological features, etc. Such situations not only slow down construction, but can also lead to unexpected costs which the investor hadn't factored into account.

The risk of increased costs results from the difficulty of estimating the actual total costs of an investment project as early as at the preparatory stage. Moreover, previously mentioned factors, such as delayed completion date, problems with obtaining the necessary documents or unexpected but necessary alterations to the project, make the cost of the investment higher than initially planned.

Disregarding the reasons behind them, the higher costs of an investment mean that developers have to squeeze profit margins. Construction costs, i.e., the costs of material and labour, make for approximately $40 \%$ of the price of $1 \mathrm{~m}^{2}$ of a newly built flat (Figure 3). One fifth of this price is the cost of land, while overhead costs, representing $12 \%$ of the flat price, are money spent on architectural design, operation, sales and other such activities. The developer's profit is estimated to be at a level of $25-30 \%$.

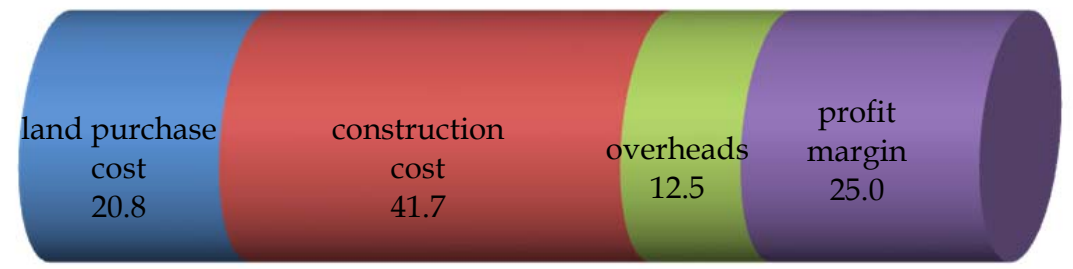

Fig. 3. Structure of the cost of $1 \mathrm{~m}^{2}$ of floor area incurred by a developer (\%). Source: own study on the basis of Rentowność projektów deweloperskich 2010.

\section{Flat Price Analysis}

If economic slowdown or disadvantageous conditions on the real estate market occur at a time a project has been completed and the sale of flats has been launched, the developer's margin is a kind of safety measure. Developers can adjust the prices of their new flats to a level that is acceptable for buyers (Figure 4). However, there is a certain point (which can transform into a line of resistance over time) below which prices cannot be lowered and developers are more likely to discontinue sales (if they can afford it) and decide to wait for a more favourable market situation.

In Figure 4, the symbol $\Delta$ signifies the value added to real estate investments. It is the difference between the selling price of a produced good (i.e., flat) and the cost of purchasing materials, prefabricated products, energy and outsourced services (BARRO 1997). This is a kind of developer's bonus for completing the investment and introducing it on the market at a specific time.

The line of resistance was determined on the basis of the conversion factor of reproduction costs of $1 \mathrm{~m}^{2}$ of floor area, which is announced every 6 months by the voivodeship governor (the head of the high-level administrative subdivision of Poland). The conversion factor is calculated separately for a voivodeship and for its capital. It is determined on the basis of the average cost of $1 \mathrm{~m}^{2}$ of floor area announced by the voivodeship division of the Central Statistical Office (GUS). When estimating the 
conversion factor, the growing costs of goods and services in the voivodeship over the last six months are taken into account as well. The line of resistance can rise when contractors lower construction costs, or rise when they decide to follow the buyers' expectations concerning workmanship standards.

Figures 5-8 show the dynamics of the average offer and transaction price of $1 \mathrm{~m}^{2}$ of floor area on the primary and secondary markets in Szczecin (Informacja o cenach mieszkań... 2012) in relation to the line of resistance. The Figures also include the actual costs of housing investments. The data were collected in a survey conducted among local developers. The analysis covered the subsequent quarters of 2007-2012. A forecast regarding the average price of $1 \mathrm{~m}^{2}$ of floor area was made for the following year on the basis of exponential smoothing (CIEŚLAK 2000) using STATISTICA ${ }^{1}$.

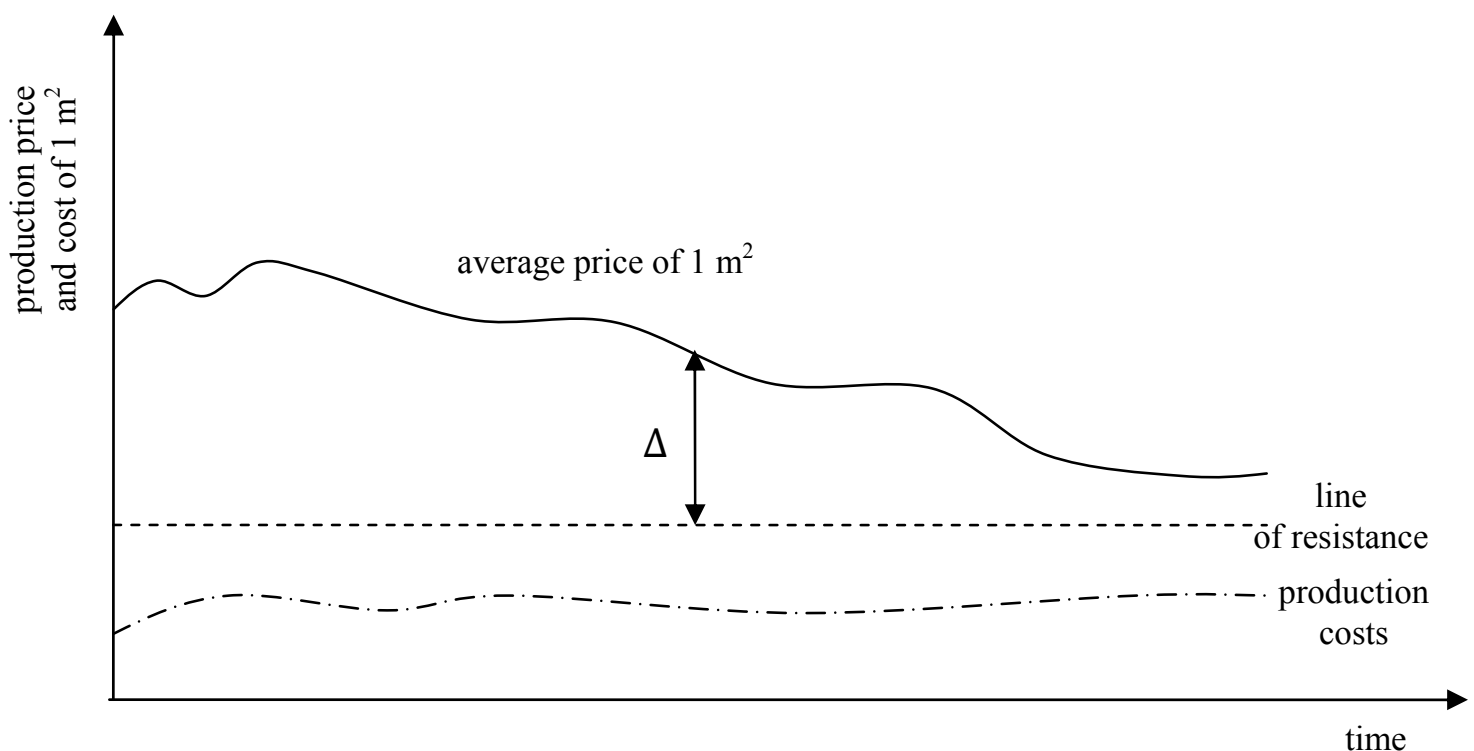

Fig. 4. Relation between price and cost of producing $1 \mathrm{~m}^{2}$ of floor area. Source: own study.

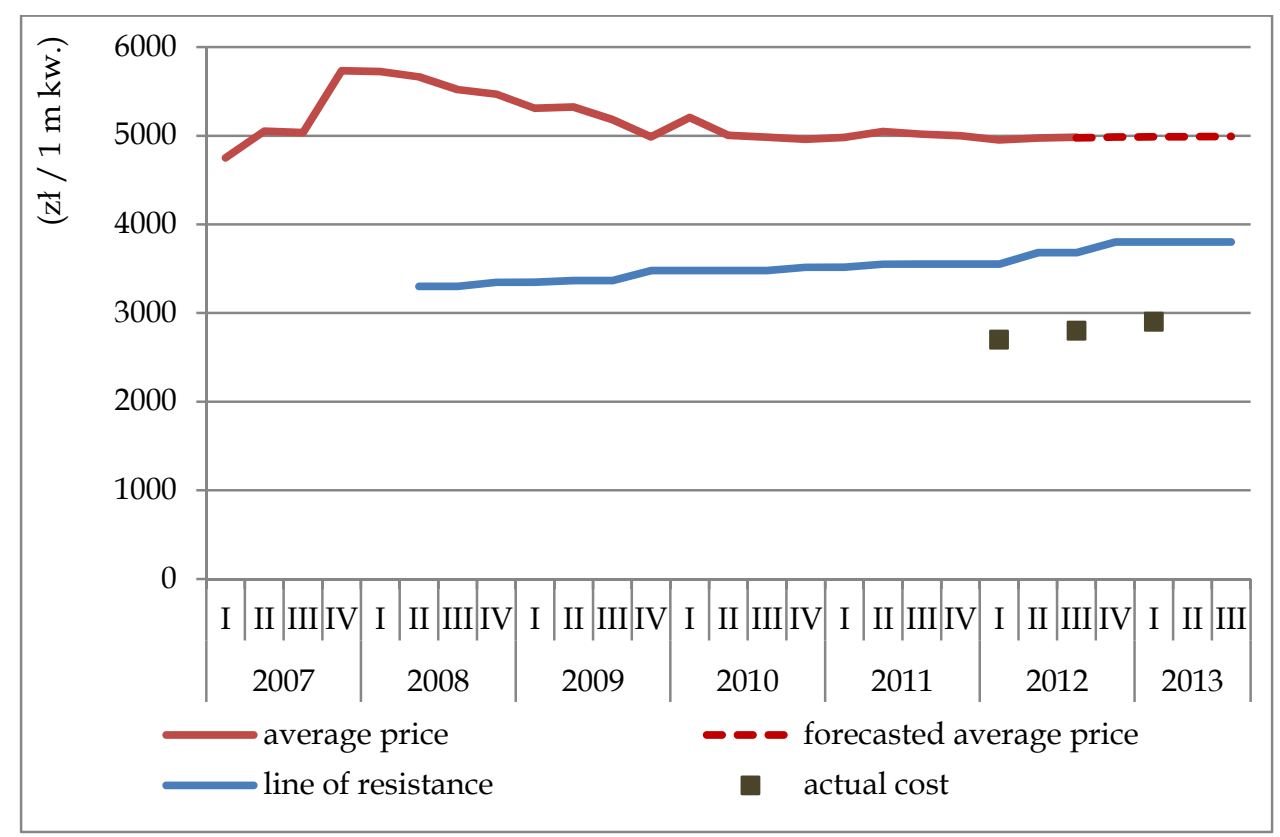

Fig. 5. Offer prices on the primary market, line of resistance and actual production costs of $1 \mathrm{~m}^{2}$ of floor area in Szczecin from Q1 2007 to Q3 2012 and the forecast for the following year (PLN/1m²). Source: own study.

\footnotetext{
1 StatSoft, Inc. (2011). STATISTICA (data analysis software system), version 10. www.statsoft.com.
} 
In Szczecin the average offer price of $1 \mathrm{~m}^{2}$ of floor area had been steadily falling since 2008. The developers' expectations concerning this price were adjusted from quarter to quarter. Since the second half of 2010, the expected price stabilized at PLN 5,000 per $1 \mathrm{~m}^{2}$ of floor area, whereas the line of resistance indicated a steady growth of investment costs. In 2008, added value exceeded PLN 2,300 and then dropped to PLN 1,300 in 2012.

Transaction prices are prices that the developers actually get for $1 \mathrm{~m}^{2}$ of floor area. These were generally lower than the offer prices (Figure 6), which indicates the developers' readiness to lower prices at the last stage of the sale, i.e., when negotiating contracts with individual clients. In 2008, buyers could expect as much as a 20\% discount (PLN 900 per $1 \mathrm{~m}^{2}$ ). In 2012, the transaction price stabilized at PLN 4,700/1 $\mathrm{m}^{2}$ (i.e., 5\% below the offer price). This means that the developers had good business sense and adjusted their offers well to the buyers' expectations and their financial potential.

The differential $\Delta$ ranged from PLN 2,300 in the 3rd quarter of 2008 to PLN 1,000 in the 3rd quarter of 2012. According to the 2014 forecast, the relation between price and production cost is going to level off. Added value is not expected to go down.

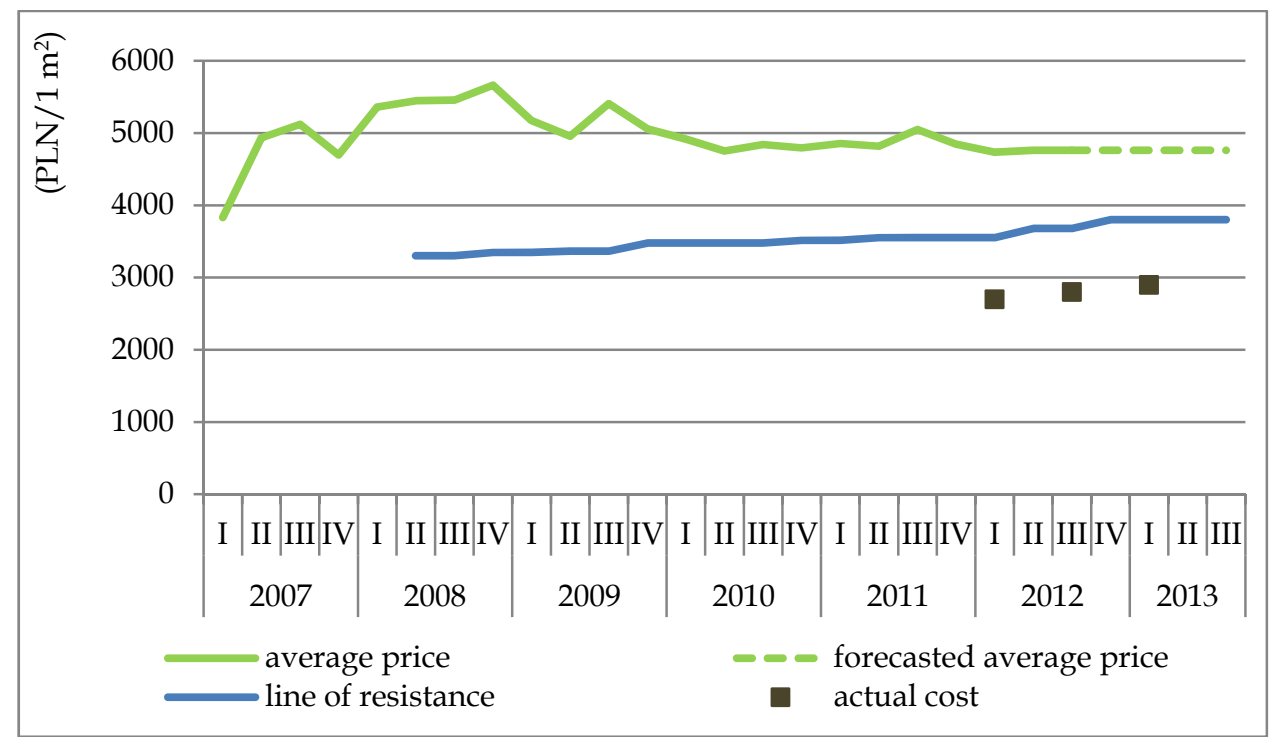

Fig. 6. Transaction prices on the primary market, line of resistance and actual production costs of $1 \mathrm{~m}^{2}$ of floor area in Szczecin from Q1 2007 to Q3 2012 and the forecast for the following year (PLN/1m²). Source: own study.

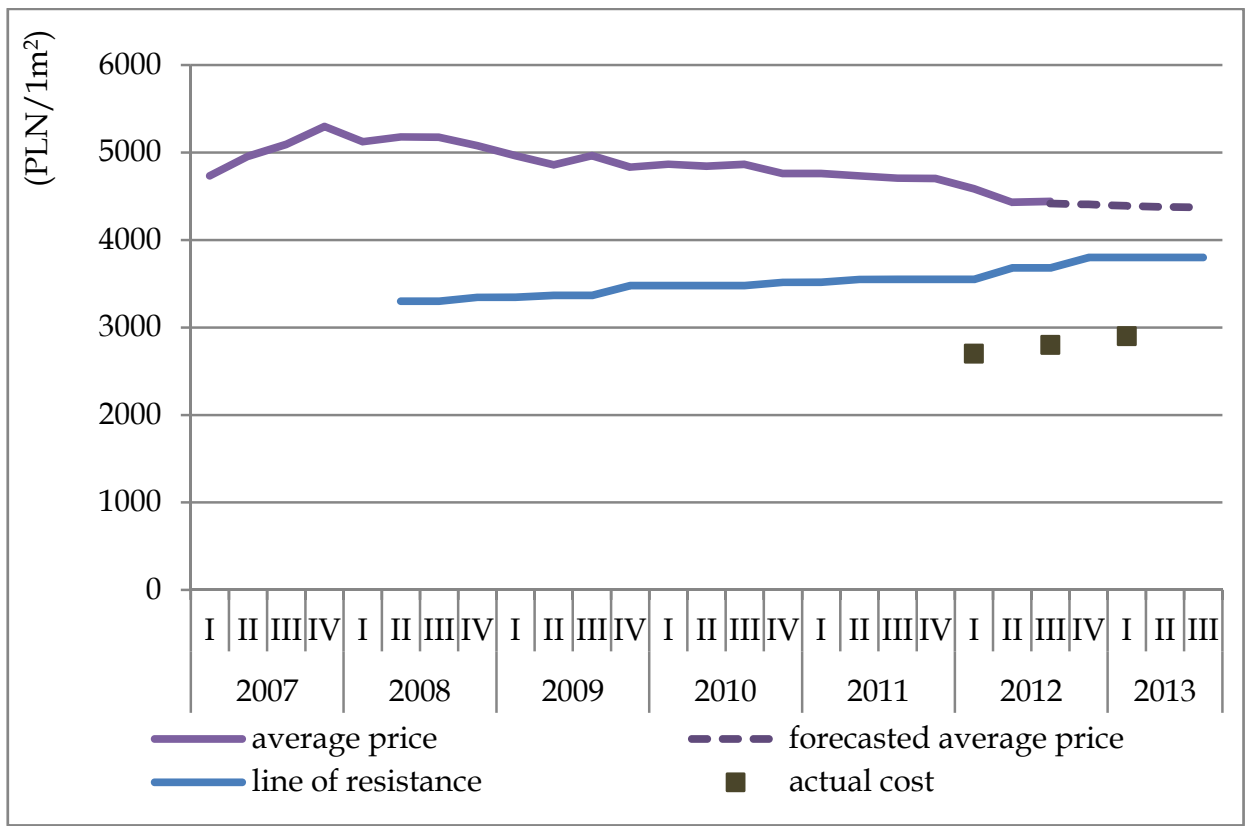

Fig. 7. Offer prices on the secondary market, line of resistance and actual production costs of $1 \mathrm{~m}^{2}$ of 
floor area in Szczecin from Q1 2007 to Q3 2012 and the forecast for the following year (PLN/1m²). Source: own study.

A common consequence of purchasing a flat on the primary market is its resale on the secondary market. The prices on the latter market are a derivative of the transactions on the former one. In 20072012, the trends in the average offer and transaction prices of $1 \mathrm{~m}^{2}$ of floor area on the secondary market in Szczecin were similar to those noted on the primary market (Figure 7 and 8). The highest offered prices were observed near the end of 2007 (PLN 5,300 per $1 \mathrm{~m}^{2}$ ). In 2008, the average offer price began to drop, falling to PLN 4,400 in the 3rd quarter of 2012. Transaction prices were lower by an average of $17 \%$ in relation to offer prices.

The highest average transaction prices of $1 \mathrm{~m}^{2}$ were observed in the second half of 2008 (PLN 4,800 ). Starting in 2009 , they were gradually adjusted from quarter to quarter. In the 3rd quarter of 2012, the average transaction was PLN 3,800 per $1 \mathrm{~m}^{2}$, which was similar to transaction prices in the quarter commencing the analysis (i.e., the 1st quarter 2007). According to forecasts, both of these prices will continue to fall.

In the case of offer prices, the value of $\Delta$ ranged from PLN 1,900 in the 2nd quarter of 2008 to PLN 780 in the 3 rd quarter of 2012. As far as average transaction prices are concerned, the value of $\Delta$ reached a high of PLN 1,500 in the $3^{\text {rd }}$ quarter of 2008, only to start decreasing gradually in the subsequent quarters. The 3rd quarter of 2012 saw the secondary market transaction prices level off with the line of resistance; they are expected to fall below the reproduction cost.

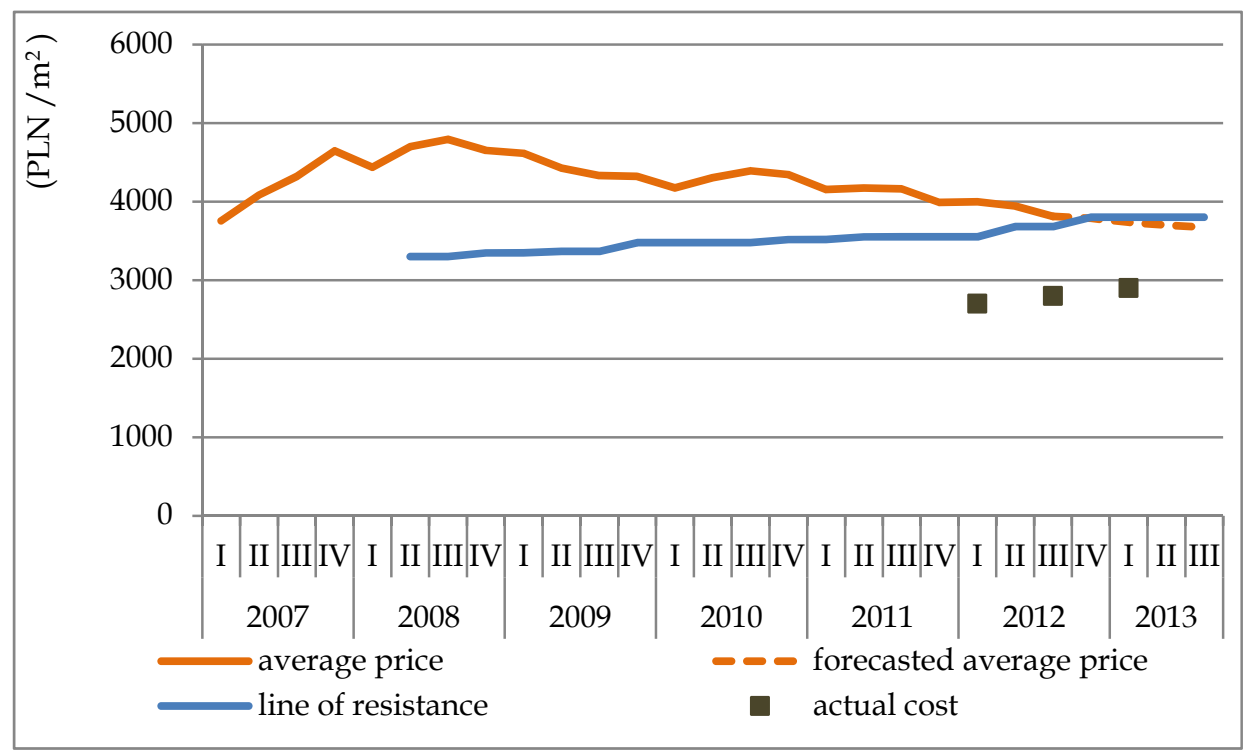

Fig. 8. Transaction prices on the secondary market, line of resistance and actual production costs of $1 \mathrm{~m}^{2}$ of floor area in Szczecin from Q1 2007 to Q3 2012 and the forecast for the following year (PLN/1 $\left.\mathrm{m}^{2}\right)$. Source: own study.

\section{Summary}

When introducing new residential investments to the market, developers decide on the price of 1 square meter. In their estimations, they take into account the total costs of their investment and the financial capacity of potential buyers. Therefore, the ultimate price contains reproduction costs and the developers' profit margin, i.e., the added value of the investment. In the longer perspective, the reproduction cost forms the line of resistance below which developers are not willing to sell newly built flats.

In 2012, the housing market, just as the rest of economic sectors, was in a state of stagnation. Growing unemployment and financial insecurity which affected many households led to a situation where potential buyers of residential real estate lost their creditworthiness. Consequently, the difficult access to sources of capital on the real estate market in Szczecin resulted in the correction of prices of 1 $\mathrm{m}^{2}$ of floor area. Falling prices affected not only the primary but also the secondary market of flats. Real estate owners no longer expected to obtain high prices from buyers (their offer prices went down). What is more, their reduced expectations were additionally verified by the buyers who 
managed to negotiate even lower prices (transaction prices were lower than those offered). The line of resistance demonstrated quite the opposite tendency. Reproduction cost was growing in each following quarter, while added value was shrinking.

Both difficulties in selling the existing flats and the uncertain buying potential of local households made developers plan their future investments more carefully (vide the falling number of construction permits and fewer residential real estate investments) and adjust their functionality to the new market situation (smaller floor size of individual flats).

The average transaction prices of $1 \mathrm{~m}^{2}$ of floor space sold on the secondary market in Szczecin reached the level of reproduction cost. In the case of the remaining analyzed prices, the security level was not crossed and the selling prices of $1 \mathrm{~m}^{2}$ were still higher than the costs of production. It should be noted, however, that all prices had been dropping since 2008, while the line of resistance revealed an upward tendency. These lines are expected to intersect, i.e., prices are likely to fall below the cost level in the 1st quarter of 2015 at PLN 4,000 in the case of offer prices on the secondary market and at PLN 4,200 in the 3rd quarter of 2016 in the case of transaction prices on the primary market. Secondary market transaction prices have already reached this value. Such a situation will take place when ceteris paribus is assumed.

The average transaction price of $1 \mathrm{~m}^{2}$ of floor space for a new flat may fall below the line of resistance, provided the costs of production are reduced as well. However, since the economic situation is changing dynamically, it is rather unlikely for prices to fall below that line. In the 4 th quarter of 2012, the developers' optimism concerning sales increased. In just the previous quarter, they had estimated that they would need about 7.5 quarters ( 2 years) to sell out their existing offer, whereas in the $4^{\text {th }}$ quarter, their predictions anticipated 6.5 quarters.

\section{References}

Bank Danych Lokalnych, Główny Urząd Statystyczny, http:/ / www.stat.gov.pl/bdl.

BARRO R.J., 1997, Makroekonomia, PWE, WARSZAWA.

CIEŚlAK M., (red.) 2000, Prognozowanie gospodarcze. Praca zbiorowa, Wydawnictwo Naukowe PWN, Warszawa.

DĄBROWSKI M., KIREJCZYK K., 2001, Inwestycje deweloperskie, Twigger, Warszawa.

Dziennik Urzędowy Województwa Zachodniopomorskiego. 2012.

GAWRON H., 2006, Opłacalność inwestowania na rynku nieruchomości, Wyd. AE w Poznaniu, Poznań.

Informacja o cenach mieszkań $i$ sytuacji na rynku nieruchomości mieszkaniowych $i$ komercyjnych w Polsce, 2012, NBP.

Rentowność projektów deweloperskich, 2010, CEE Property Group Sp. z o.o. 